Journal of Jazz Studies vol. 10, no. 1, pp. $72-77$ (Summer 2014)

\title{
Charlie Parker: Two New Bios And A Revision Crouch, Haddix and Giddins
}

\author{
Jeff Sultanof
}

Kansas City Lightning: The Rise and Times of Charlie Parker. By Stanley Crouch. New York: NY: HarperCollins Publishers. 384 pp.

Bird: The Life and Music of Charlie Parker. By Chuck Haddix. Urbana: University of Illinois Press. 224 pp.

Celebrating Bird: The Triumph of Charlie Parker (Revised Edition). By Gary Giddins. Minneapolis: University of Minnesota Press. 208 pp.

"We were playing white dances, and during intermission you couldn't go out into the audience, so you stayed backstage. I was sitting at the piano, fooling around with something. Some white guy said, 'Hey ...' to me and thumped a nickel on the stand. And then he said, 'When you come back on, play so-and-so' ... I looked down at the nickel and up at this dude, and picked up the nickel and threw it someplace, and just kept playing. Later on that night, after the dance was over, I thought everyone had left and we could go to the 'white' men's room. While they were dancing, all the men's rooms were white, and the women's too. Anyway, I went in and came out of the men's room, and as I was coming out I saw this shadow behind my head coming down. This bottle was coming at my head. So I just happened to turn, just a little bit, and the guy caught me in the back of the head with this bottle. I turned around and was just getting ready to hit this guy when about five guys grabbed me. And then Charlie Parker came along. Charlie Parker walked over to the guy who hit me and said, 'You took advantage of my friend, you cur!' He called the guy a 'cur.' The guy probably didn't even know what a cur was, man."

Charlie Parker was one of several artists who changed the course of music. Like Bach, Wagner and Coltrane, his life work has inspired musicians of all stylistic genres, and added considerably to the art of jazz harmonically and

\footnotetext{
${ }^{1}$ Dizzy Gillespie with Al Fraser. To Be or Not to Bop (New York: Quartet, 1982), quoted in Haddix.
}

copyright by authors (c) Except where otherwise noted, this work is licensed under http://creativecommons.org/licenses/by-nc-nd/3.0 
rhythmically. For musicians and the jazz fan, he was one of the key voices for a style that was called 'bebop' but was simply the modern jazz of its time.

Parker was a saxophonist who grew up in Kansas City and lived the same sort of life as most jazz players during the forties and fifties: playing large ensemble and small group gigs as a sideman and later as a leader from place to place, playing on the radio and making commercial records. Those records, combined with unauthorized live recordings, private recordings, and transcribed radio broadcasts have filled the marketplace and the internet in various levels of sound quality for years, and will certainly continue. It is even likely that there is still unknown Parker waiting to be unearthed from an unlikely source. Ross Russell began his book on Parker describing the private recordings of Parker made by fan Dean Benedetti, but who knew back then that they would be found and legally released by Mosaic, so far the only boxed set the company offers that will never go out of print.

If asked, most people who interacted with Parker considered him one of the most colorful personalities in the world of jazz. Very street but also quite elegant when it suited him (influenced by Duke Ellington and Hollywood movies), calling a white racist dance patron a mongrel dog probably gave him greater satisfaction than calling the man any number of epithets perhaps more appropriate (and all too readily used in media today). Many people have gone on record telling of hearing him, playing gigs with him, hanging with him, in some cases loving him, and having their lives touched by him, both very positively and very negatively. While he is certainly recognized as a great artist, like Bix Beiderbecke, Chet Baker and Billie Holiday, his life is often romanticized as that of a genius who died too young, leaving some amazing music and influencing musicians to this day. In addition, Chan Parker, one of his wives who may not have been legally married to him, has stated that he often enjoyed the company of those who knew nothing about music and did not know who he was.

Parker was the classic example of the brilliant musician who also had long-standing alcohol and drug habits; many of his fans and musical followers were inspired to indulge in hard drugs in order to be more like him. His addictions contributed to his chameleonic nature: gracious, encouraging and dependable on the one hand, unpredictable, unreliable and self-destructive on the other. Although some who have written of him are forgiving of his behavior and others have even painted him as a misunderstood genius, he had a number of hit records and could have even made money as a composer for television and motion pictures just as Benny Carter, Oliver Nelson, and J.J. Johnson did. But by the 1950s, his habits were destroying his music, his professional reputation, his marriage and ultimately his life; everything came 
crashing down as he was watching "Stage Show," a half-hour variety program co-hosted by one of his inspirations on the alto saxophone, Jimmy Dorsey.

For some years after his death, information about Parker was sketchy at best; much of his activity during the $1939-40$ period is still open to conjecture. But in 1962, Robert Reisner's compilation of short oral histories about Parker was published by Citadel Press (and subsequently reissued by Da Capo Press in 1977). Invaluable as using first-hand accounts, the memories of some participants were often not very accurate, and like all oral histories, the material must be carefully considered if one wants to quote from it. It was a start though, his story told by several people who knew and interacted with him.

In 1973, Ross Russell's biography of Parker was published, and while the author knew Parker personally and even produced a number of his classic recordings, the many inaccuracies and self-serving passages in this book made it a questionable source. It was published during a time when biographies of jazz artists were not usually researched extensively or annotated with footnotes, but at least it was a first try at a biography of Parker, and inspired others to further explore the world of the saxophonist and try to dig out the truth. It was Russell who pointed out that Parker was hardly a child prodigy; he'd worked hard as a teenager to attain the harmonic and technical prowess he later used to great advantage when he began impressing such musicians as Ben Webster and Buster Smith. It certainly hinted at aspects of the man's life that were ripe for further study.

The first great book on Parker is one of the volumes discussed here. When Celebrating Bird: The Triumph of Charlie Parker was first published in 1987, Gary Giddins' long biographical essay corrected misleading information, and drew from new interviews with Parker's first wife Rebecca, bandleader Jay McShann, and a variety of others. It also had a lot of pictures, making it as important not only as text but as a graphic study of a man's life, his influences, and the atmosphere in which he developed and practiced his art. In this new edition, Giddins has left the text pretty much alone except by restoring material he'd cut, and in his words, "tighten the gears." 2 This is a beautiful presentation by the University of Minnesota Press, and if you have the older Birch Tree Books publication, I would still encourage upgrading to this edition.

Giddins has included two discographies: the original 1987 listing of LPs, and a new discography of CDs. Reprinting the original discography is very valuable for the researcher as a quick guide to what was available back then, and by comparing it to the new discography, Giddins reminds us of the

${ }^{2}$ Giddins, pg. xv. 
precarious state of the recording industry, the confusion of copyright laws, and the inconsistent support for jazz recordings by major labels. While it could be argued that obtaining every known recording of Parker is easily done because of the 'miracle' of the internet, the sad fact is that certain labels once legitimized the release of some of this music (e.g. Columbia Records), and the artist and/or their estates were making some money from these releases. Since these releases are no longer in print, we must be content with overseas labels where the recordings are in the public domain, and I wonder who, if anyone, is getting paid.

Chuck Haddix's book aspires to "separate the man from the myth" which has "proved to be an elusive effort for those who have written about Parkeruntil now." One wonders why he would write such a statement. Giddins' elegant volume is now considered a classic text, and if any book has demythologized Parker's life, it is his, putting Mr. Haddix on uneven territory before he really begins. Haddix or the publisher tells us that the book is "meticulously researched" with new information, but except for a few interviews Haddix conducted on his own, mostly everything here can be found elsewhere. For those who feel that I might be unduly hard on Mr. Haddix, this book initially seems like a handy little volume which does quote from sources that may be hard for the casual reader to find (a Rebecca Parker interview from a 'local' publication called The Pitch, as well as quotations from such newspapers as the Kansas City Star), but I am troubled when I find John S. Wilson's name printed as "Jon" in the notes section. And to call Lennie Tristano a practitioner of "the latest movement in jazz, which later became known as the third-stream" ${ }^{3}$ is simply incorrect and tells me that the author either did not listen to Tristano, or does not understand what 'third stream' is. ${ }^{4}$ A typo is one thing; misleading information another. The book does have some photos I've not seen elsewhere, and a photo of Dean Benedetti and Max Roach 'escorting' (Haddix's words) Parker out the back door of the Three Deuces disturbed me. Roach and Parker may be smiling, but Benedetti is visibly upset, leading me to believe that Parker was having one of his 'bad' evenings, of which many were legendary. They would have included any and/or all of the following: coming late, being missing from the bandstand for a long time to shoot up, playing poorly because he was high, etc., etc. This

\footnotetext{
${ }^{3}$ Haddix, pg. 126

${ }^{4}$ The term was devised by Gunther Schuller at a lecture at Brandeis University in 1957. Although Tristano's groups warmed up playing Bach, his music could hardly be considered 'third stream.'
} 
photo brings back all of this for me. Including it is may be in questionable taste just to get a 'new' photo into circulation.

The last book under discussion took me totally by surprise. I confess I am always suspicious of multi-volume biographies; somehow, one has to wonder if all of them will ever be available (notice to Mr. Giddins: I am still waiting for volume 2 of your Bing Crosby biography, since volume 1 was excellent). It was well known for years that Stanley Crouch began working on a biography of Charlie Parker back in the 1980s. He interviewed many key players in the Parker story who are no longer living, and even shared some of his interviews with other writers (it was Crouch who first interviewed Parker's first wife Rebecca Ruffin and generously shared it with Gary Giddins for Celebrating Bird). Crouch has finally gone public with a book that covers Parker's life until the late thirties, and has created an instant classic that will have wide appeal, from scholars and fans to those who may have heard Parker's name but don't know anything about him.

In Crouch's telling, Parker is put into a rich context of life during the thirties in a place called Kansas City, where a political machine allowed all sorts of illegal operations to flourish, and was a hotbed for a type of swinging jazz that became known all over the world. With a novelist's sensibility, he creates a vivid picture of a young boy whose father disappeared, and whose mother indulged him so that he had few boundaries or self-discipline. Parker also lost his best friend, seemingly the one person who believed in him when bandleaders wanted to fire him; Crouch tells us that Parker would not let anyone get that close to him for the rest of his life. Crouch portrays Parker's world more vividly than anything I have ever read previously. Rather than describing this, a sample should suffice:

Silent but observant, Charlie hung around the yard behind the club, his horn in his sack, his appetite staved off by chicken from one of the local chuck wagons. When his nerve was up, young Charlie would cadge a cigarette and stand off to the side with his hand in his pocket ... He spent many a night at the back door listening to the Basie rhythm section's superb introductions, to the blend of the saxophones, the stinging brass. ${ }^{5}$

Crouch uses his novelistic gifts so that the reader 'gets' the sights, smells and attitudes of Parker's world. When discussing Parker's married life with Rebecca, he often writes from her point of view, enabling us to experience her dismay, upset and confusion dealing with an addicted boy she loved and his

${ }^{5}$ Crouch, pg. 150 
overprotective mother. Parker 'lives' in Crouch's telling, backed by the most up-to-date information of his musical activities. One hopes that the second volume of Crouch's biography does not take too long to arrive in bookstores.

Biographies are always works in progress as new information always turns up, and 'facts' are always open to interpretation, but the Giddins and now the Crouch books are worth the readers' money and time.

\section{About the Contributor}

JEFF SULTANOF is a composer/arranger/conductor/historian who edits and corrects jazz ensemble performance materials from original sources; over 400 of them are published by Jazz Lines Publications. He has written numerous articles on American music, chief among them "The Miles Davis Nonet Manuscripts Lost and Found: From Manuscript to Publication" (Journal of Jazz Studies, Vol. 7, No. 2 (Fall 2011). He is currently writing "Big Band Jazz: A Listener's Companion" to be published by Scarecrow Press in 2016.

The Journal of Jazz Studies (JJS) is published by the Institute of Jazz Studies at the Newark campus of Rutgers, The State University of New Jersey. JJS is hosted online by the Rutgers University Libraries at http://jjs.libraries.rutgers.edu. 